\title{
Penerapan Metode Find Someone Who Untuk Meningkatkan Kemampuan Berbicara Bahasa Inggris Siswa
}

\author{
Nurteteng $^{1}$, Winarsih ${ }^{2}$ \\ Universitas Pendidikan Muhammadiyah Sorong ${ }^{1}$, SMP Muhammadiyah Aimas ${ }^{2}$ \\ teteng.syaid72@gmail.com, winarsih53@yahoo.com
}

\begin{abstract}
Abstrak. Tujuan penelitian ini adalah untuk meningkatkan kemampuan berbicara siswa dalam bahasa inggris menggunakan metode Find Someone Who. Permasalahan dalam penelitian ini adalah rendahnya kemampuan berbicara siswa yang terlihat dari hasil pretesnya yaitu 41.4 dan termasuk dalam kategori buruk. Jenis penelitian adalah penelitian tindakan kelas (classroom action research) yang dilakukan dalam 2 siklus, masing -masing siklus terdiri dari 4 tahap, yakni perencanaan, pelaksanaan, observasi dan refleksi. Setiap siklus dilakukan 3 kali pertemuan. Subyek penelitian ini adalah siswa kelas VII B SMP Muhammadiyah Aimas dengan jumlah siswa 17 orang yang terdiri dari 12 siswa laki -laki dan 4 siswa perempuan. Pada siklus I, pertemuan I dari 17 siswa yang mengikuti tes berbicara, terdapat 9 siswa ( 53\%) dikategorikan memiliki skor yang cukup, 7 siswa (41\%) dikategorikan memiliki skor yang cukup baik dan 1 siswa (6\%) dikategorikan memiliki skor yang baik. Hal ini menunjukkan bahwa penggunaan metode Find Someone Who belum berhasil sehingga perlu dilakukan refleksi untuk ditindaklanjuti pada siklus II. Hasil tes formatif siklus II menunjukkan masih ada 2 siswa (12\%) yang dikategorikan memiliki skor yang cukup baik, 11 siswa (65\%) memiliki skor yang baik dan 4 siswa (24\%) memiliki skor yang sangat baik. Berdasarkan hasil penelitian tersebut dapat disimpulkan bahwa penggunaan metode Find Someone Who dapat meningkatkan kemampuan berbicara bahasa inggris siswa.
\end{abstract}

Kata Kunci: Berbicara, Find Someone Who.

Abstract. The purpose of this research is to improve the students speaking skill towards Find Someone Who method. The problem of this research is the students speaking skill that is very low and it can be detected from the pretest result, that is 41.4 and it categorized into poor classification. This research used classroom action research which has been done into two cycles and every cycle consist of 4 steps. They are planning, action, observation and reflection. Every cycle has been done in 3 meetings. The subject of this research is VII B students of SMP Muhammadiyah Aimas with the number of students is 17 students. They are consist of 12 men and 4 women. At the cycle 1, all the students followed speaking test. The result is 9 students or 53\% of them categorized into poor score, 7 students or $41 \%$ of them categorized into fairly good score, and 1 students or $6 \%$ of them categorized into good score. It showed that the implementation of Find Someone Who method hasn't reached the KKM and research target. So, this research continued into the cycle 2. The result of the cycle 2 showed that 2 students or $12 \%$ of them categorized into fairly good score, 11 students or $65 \%$ of them categorized into good score, and 4 students or $24 \%$ of them categorized into very good score. At the end, it can be concluded that the implementation of Find Someone Who can improve the students speaking skill.

Keywords: Speaking Skill, Find Someone Who. 


\section{Pendahuluan}

Kebutuhan Bahasa inggris di era milenial sekarang ini merupakan salah satu primary needs yang harus di miliki oleh para generasai muda khususnya pelajar. Kemajuan teknologi yang semakin cepat memaksa mereka untuk menguasai Bahasa inggris. Pada era yang pesat ini semua alat komunikasi seperti laptop, handphone dan game semuanya menggunakan bahasa inggris sebagai bahasa pengantarnya. Sehingga memaksa para generasi milenial ini untuk mau tidak mau harus belajar dan menguasai bahasa inggris dengan baik. Hal ini senada dengan pernyataan Tsui dan Tollefson (2007) menambahkan bahwa jika ingin mengakses ilmu pengetahuan dan teknologi, maka harus memiliki pemahaman tentang penggunaan bahasa Inggris.

Kemampuan bahasa inggris seseorang salah satunya dapat diukur dari kemampuan berbicaranya. Tahir (2015) menyatakan bahwa seseorang dianggap sukses mempelajari sebuah bahasa asing ketika mereka mampu menggunakan bahasa tersebut dalam berbicara. Berbicara adalah proses penyampaian pesan atau informasi dari seorang pembicara kepada seorang pendengar. Thornbury (2006) menyatakan bahwa berbicara adalah suatu hal yang alamiah dan integral sehingga kita lupa bagaimana pertama kali memperoleh dan mampu berbicara, karena itu ketika kita ingin menguasai bahasa asiing kita harus belajar kembali.

Dari perspektif dunia pendidikan khususnya di sekolah, seorang siswa dituntut untuk mempu berkomunikasi menggunakan bahasa inggris dalam mengutarakan pendapatnya. Selain, mereka juga harus bisa mengajukan pertanyaan dan merespon pertanyaan dari orang lain menggunakan bahasa inggris. Tuntutan tersebut sebenarnya sudah tertuang dalam Standar Kompetensi Lulusan melalui Permendikbud Nomor 54 Tahun 2013 mengenai kualifikasi kemampuan lulusan yang mencakup sikap, pengetahuan, dan keterampilan.

Pada kenyataannya, kemampuan berbicara siswa hanya bisa di mereka aplikasikan dalam mengerjakan tugas atau latihan tertulis dalam buku pelajaran mereka. Dalam proses pembelajaran hamper tidak ada siswa yang berani berbicara menggunakan bahasa inggris didepan kelas. Keadan kelas bahasa Inggris yang seharusnya ramai dengan praktik berbicara malah sunyi dan membosankan. Kurangnya minat siswa dalam belajar bahasa inggris karena dianggap susah dan tidak penting menambah tidak hidupnya suasana pembelajran yang efektif di dalam kelas. Hakikat akan pengaplikasian Kurikulum 2013 yang seharusnya menuntut siswa untuk lebih banyak praktek mengajar terabaikan dengan metode mengajar gurunya yang masih menggunakan metode KTSP walaupun rencana pelaksanaan pembalajarannya sudah menggunakan Kurikulum 2013.

Ada beberapa faktor yang menyebabkan keadaan pembelajaran bahasa inggris khususnya berbicara memprihatinkan seperti ini. Pertama, siswa menganggap bahwa bahasa inggris itu merupakan pelajaran yang susah sehingga siswa tidak ada motivas untuk mempelajarinya. Kedua, metode mengajar yang di rancang oleh guru hanya berbasis grammar (pengajaran struktur bahasa). Guru hanya mengajarkan teori yang tidak jelas arah dan penggunaannya dan kurang praktek berbicara. Sehingga walaupun mereka sudah mempelajari bahasa inggris bertahun-tahun tetapi mereka tetap tidak bisa berbicara menggunakan bahasa inggris dengan fasih. Ketiga, dasar pengetahuan bahasa inggris yang dimiliki oleh siswa kelas VII sangat kurang dikarenakan mereka tidak belajar bahasa inggris di sekolah dasar. Sehingga, untuk siswa kelas VII SMP bahasa Inggris merupakan hal yang baru dan aneh menurut mereka.

Pertimbangan diatas yang menjadi latar belakang penulis untuk melakukan peningkatan kemampuan berbicara siswa menggunakan salah satu metode pembelajaran kooperatif yaitu metode Find Someone Who. Jumrawasi (2017) menyatakan pembelajaran kooperatif dapat didefinisikan sebagai suatu pendekatan mengajar dimana murid-murid dalam kelompok belajar yang kecil untuk menyelesaikan tugas individu atau kelompok 
yang diberikan oleh guru. Dengan menggunakan pembelajaran kooperatif dapat melibatkan siswa secara aktif dengan metode perbincangan secara individu maupun kelompok. Metode ini sangat sesuai digunakan untuk meningkatkan kemampuan berbicara siswa dalam bahasa inggris. Suherman (2003) menyatakan bahwa pembelajaran kooperatif mencakup suatu kelompok kecil siswa yang bekerja sebagai sebuah tim untuk menyelesaikan sebuah masalah, menyelesaikan suatu tugas, atau mengerjakan sesuatu untuk mencapai tujuan bersama lainnya.

Metode Find Someone Who yang termasuk dalam pembelajaran kooperatif dikembangkan oleh Spencer Kagan (2009). Find Someone Who adalah aktifitas pembelajaran yang mendorong siswa untuk berpikir secara dinamis dan siap menjawab pertanyaan secara langsung dari siswa yang lain yang tertera dalam worksheet (lembar kerja). Sintaksis metode pembelajaran ini menurut Jamrawasi (2017) dalam penelitiannya adalah pada tahap pertama seorang siswa diberi semacam worksheet oleh guru atau lembaran kerja yang ada pertanyaannya. Pada tahap kedua siswa yang memegang worksheet tersebut kemudian berkeliling kelas "menjajakan" lembaran kerja tersebut, dan harus dijawab oleh teman sekelas yang didatanginya dengan jawaaban "ya" jika pertanyaannya sesuai dengan dirinya. Setelah selesai menjawab pada kolom yang disediakan, siswa yang menjawab itu harus membubuhkan namanya disamping jawabannya. Pada tahap ketiga demikian seterusnya sampai siswa diseluruh kelas telah melengkapi lembar kerjannya dan melaporkannya di depan kelas. Tujuan dari penelitian ini adalah untuk meningkat kemampuan berbicara siswa dalam bahasa Inggris menggunakan metode Find Someone Who.

\section{Metode Penelitian}

Penelitian ini menggunakan metode penelitian tindakan kelas (Action Research). Subjek dari penelitian adalah adalah siswa kelas VII B SMP Muhammadiyah Aimas yang berjumlah 17 orang. Denzin dan Lincoln (2011) menyatakan penelitian tindakan kelas pada umumnya mencakup model-model penelitian dan pengumpulan data interpretatif kualitatif oleh guru dengan tujuan agar para guru mampu memberikan penilaian dan evaluasi tentang cara dan teknik untuk meningkatkan praktik pengajaran mereka sendiri. Dari pendapat tersebut, maka peneliti melibatkan salah seorang guru bahasa inggris di sekolah tersebut sebagai partner dalam penelitian ini. Alat pengumpul data penelitian ini mencakup test, observasi dan dokumentasi. Untuk mengukur peningkatan berbicara siswa, peneliti menggunakan test berbicara yang direkam langsung menggunakan video. Sedangkan observasi digunakan untuk melihat keaktifan siswa dalam proses pembelajaran yang dilalukan oleh partner peneliti serta dokumentasi seperti video pembelajaran dan foto.

Penelitian ini diawali dengan tahap perencanaan yang meliputi perencanaan, penyusunan perangkat pembelajaran dan instrumen penelitian. perangkat pembelajaran meliputi rencana pelaksanaan pembelajaran, materi pelajaran, media pembelajaran, lembar kerja find someone who. Setelah itu dilakukan pelaksanaan berupa pengajaran menggunakan metode find someone who sebanyak 2 siklus dimana satu siklus terdiri dari 3 kali pertemuan. Tahap akhir yaitu pelaporan yang berasal dari hasi analisis data pretest dan posttest setiap siklus dan hasil observasi dalam kelas. Data hasil penelitian ini dianalisis menggunakan teknik analisis data kuantitatif. Peningkatan skor yang ditargetkan dalam penelitian ini, nilai rata-rata yang dicapai oleh siswa secara keseluruhan adalah 80 . Data hasil pretest dan posttest dari setiap siklus di klasifikasikan dalam menurut tabel klasifikasi kemampuan berbicara seperti dibawah ini. 
Tabel 1. Tabel Klasifikasi Skor Kemampuan Berbicara

\begin{tabular}{ccc} 
No & Klasifikasi & Skor \\
\hline 1 & Sempurna & $96-100$ \\
2 & Sangat Baik & $86-95$ \\
3 & Baik & $76-85$ \\
4 & Cukup Baik & $66-75$ \\
5 & Cukup & $56-65$ \\
6 & Buruk & $36-55$ \\
7 & Sangat Buruk & $00-35$ \\
\hline
\end{tabular}

\section{Hasil dan Pembahasan}

Penelitian ini diawali dengan pemberian pre-test kepada siswa berupa test kemampuan berbicaranya secara individu yang di rekam menggunakan video. Tujuan dari pretest ini adalah untuk mengetahui kemampuan awal siswa sebagai tolak ukur peneliti menentukan jumlah peningkatan skor yang harus dicapai. Dari hasil pretest terlihat bahwa kemampuan berbicara siswa masih dibawah KKM yaitu skore 65. Hal ini dapat terlihat dari tabel dibwah ini.

Tabel 2. Hasil Test Kemampuan Berbicara Siswa Pada Pre-test

\begin{tabular}{ccccc} 
No & Klasifikasi & Skor & Frekuensi & Persentase \\
\hline 1 & Sempurna & $96-100$ & 0 & 0 \\
2 & Sangat Baik & $86-95$ & 0 & 0 \\
3 & Baik & $76-85$ & 0 & 0 \\
4 & Cukup Baik & $66-75$ & 0 & 0 \\
5 & Cukup & $56-65$ & 1 & 6 \\
6 & Buruk & $36-55$ & 12 & 71 \\
7 & Sangat Buruk & $00-35$ & 4 & 24 \\
\hline & Jumlah & & 17 & 100
\end{tabular}

Tabel di atas menunjukkan bahwa di pretest (tes awal), terdapat 4 siswa atau $24 \%$ dari mereka memiliki kemampuan berbicara yang sangat buruk. Hal ini dikarenakan mereka tidak bisa memahami pertanyaan bahkan mengucapkan kata-kata dalam bahasa inggris pun tidak bisa. Terdapat 12 siswa atau $71 \%$ dari mereka memiliki kemampuan berbicara yang buruk. Persentase tersebut menunjukkan mayoritas dari mereka memiliki kemampuan berbicara dibawah rata-rata. Hal ini dikarenakan metode yang digunakan guru dalam kelas tidak didesain untuk mengajarkan berbicara tetapi tata bahasa. Tetapi ada 1 orang yang memiliki kemampuan berbicara yang termasuk dalam kategori cukup dikarenakan berdasarkan hasil wawancara langsung dengan siswanya bahwa siswa tersebut sebelumnya mempelajari bahasa inggris di tingkat sekolah dasar. Dari hasil pretest, dapat disimpulkan bahwa kemampuan berbicara siswa dala kelas tersebut jika dirata-ratakan belum mencapai KKM yaitu 70.

Setalah pretest, peneliti melaksanakan melaksanakan siklus 1 selama 3 kali pertemuan menggunakan metode find someone who. Disetiap pertemuan, materi yang diajarkan merupakan materi yang berbeda dan berkelanjutan serta mengikuti silabus dan program 
semester dari sekolah tersebut. Diakhir siklus tersebut siswa diberikan test kemampuan berbicara untuk mengetahui peningkatan siswa setelah diajar menggunakan metode Find Someone Who. Hasil test pada siklus 1 dapat dilihat dalam tabel dibawah ini:

\section{Tabel 3. Hasil Test Kemampuan Berbicara Siswa Pada Siklus}

\begin{tabular}{ccccc} 
No & Klasifikasi & Skor & Frekuensi & Persentase \\
\hline 1 & Sempurna & $96-100$ & 0 & 0 \\
2 & Sangat Baik & $86-95$ & 0 & 0 \\
3 & Baik & $76-85$ & 1 & 6 \\
4 & Cukup Baik & $66-75$ & 7 & 41 \\
5 & Cukup & $56-65$ & 9 & 53 \\
6 & Buruk & $36-55$ & 0 & 0 \\
7 & Sangat Buruk & $00-35$ & 0 & 0 \\
\hline \multicolumn{5}{c}{ Jumlah }
\end{tabular}

Hasil test pada siklus 1 diatas menunjukkan bahwa terdapat sedikit peningkatan pada kemampunan berbicara siswa setelah diajar menggunakan metode find someone who. Teradapat 9 siswa atau 53\% dari mereka yang sudah memiliki kemampuan berbicara yang cukup. Ada 7 siswa atau $41 \%$ dari mereka yang dikategorikan memiliki kemampuan berbicara yang cukup baik dan 1 orang siswa atau $6 \%$ dari mereka yang dikategorikan memiliki kemampuan berbicara yang baik. Persentase kemampuan siswa yang lebih dominan dari siklus satu yaitu $53 \%$ yang masuk dalam ketegori cukup. Hal ini menunjukkan bahwa pada siklus 1 kemampuan berbicara masih bisa ditingkatkan dan belum mencapai KKM serta target peneliti yaitu siswa harus memiliki rata-rata kemampuan berbicara sebanyak 80. Alasan tersebut yang mendasari peneliti untuk melaksanakan siklus 2. Pada siklus ini, siswa tetap diajar sebanyak 3 kali dengan melanjutkan meteri dari siklus 1 sebelumnya. Metode yang digunakan tetap menggunakan metode Find Someone Who. Hasil peningkatan kemampuan berbicara pada siklus 2 dapat terlihat dalam tabel berikut:

Tabel 4. Hasil Test Kemampuan Berbicara Siswa Pada Siklus

\begin{tabular}{ccccc} 
No & Klasifikasi & Skor & Frekuensi & Persentase \\
\hline 1 & Sempurna & $96-100$ & 0 & 0 \\
2 & Sangat Baik & $86-95$ & 4 & 24 \\
3 & Baik & $76-85$ & 11 & 65 \\
4 & Cukup Baik & $66-75$ & 2 & 12 \\
5 & Cukup & $56-65$ & 0 & 0 \\
6 & Buruk & $36-55$ & 0 & 0 \\
7 & Sangat Buruk & $00-35$ & 0 & 0 \\
\hline \multicolumn{7}{c}{ Jumlah }
\end{tabular}

Dari tabel diatas dapat dilihat bahwa ada 2 orang siswa atau $12 \%$ dari mereka yang masih memiliki kemampuan berbicara yang cukup baik. Sedangkan ada 11 orang atu $65 \%$ 
memiliki peningkatan yang cukup signifikan yaitu masuk dalam kategori baik dalam kemampuan berbicara. Bahkan ada 4 orang atau $24 \%$ dari mereka yang memiliki peningkatan kemampuan berbicara yang cukup baik. Dengan kata lain, peningkatan kemampuan berbicara siswa pada siklus 2 sudah dapat diterima dan kebanyakan siswa dalam kelas tersebut sudah memiliki kemampuan berbicara yang baik dan mencapai KKM serta target peningkatan peneliti yaitu 80. Rata-rata nilai peningkatan kemampuan berbicara siswa dalam dilihat dari tabel dibawah ini:

\section{Tabel 4. Skor Rata-Rata Nilai Siswa}

\begin{tabular}{ccc} 
Tahap & Mean & Kategori \\
\hline Pretest & 41.4 & Buruk \\
Siklus 1 & 64.8 & Cukup \\
Siklus 2 & 80.7 & Baik \\
\hline
\end{tabular}

Tabel diatas menunjukkan bahwa pada pretest rata kemampuan berbicara siswa adalah 41.4 yang dikategorikan buruk. Dengan kata lain, kemampuan berbicara siswa sangat tidak layak dan jauh dari KKM. Tetapi setelah diajar menggunakan metode Find Someone Who pada siklus 1, ada peningkatan skor sebanyak 23.4 yaitu mencapai rata-rata skor 64.8 yang masuk dalam ketegori cukup. Sedangkan pada siklus 2 peningkatan kemampuan berbicara siswa sudah cukup baik yaitu mencapai rata-rata skor 80.7 dan ratarata peningkatan skor siswa mencapai 15.9. untuk lebih jelasnya, peningkatan rata-rata skor siswa mulai dari pretest hingga siklus 2 dapat dilihat pada grafik dibawah ini:

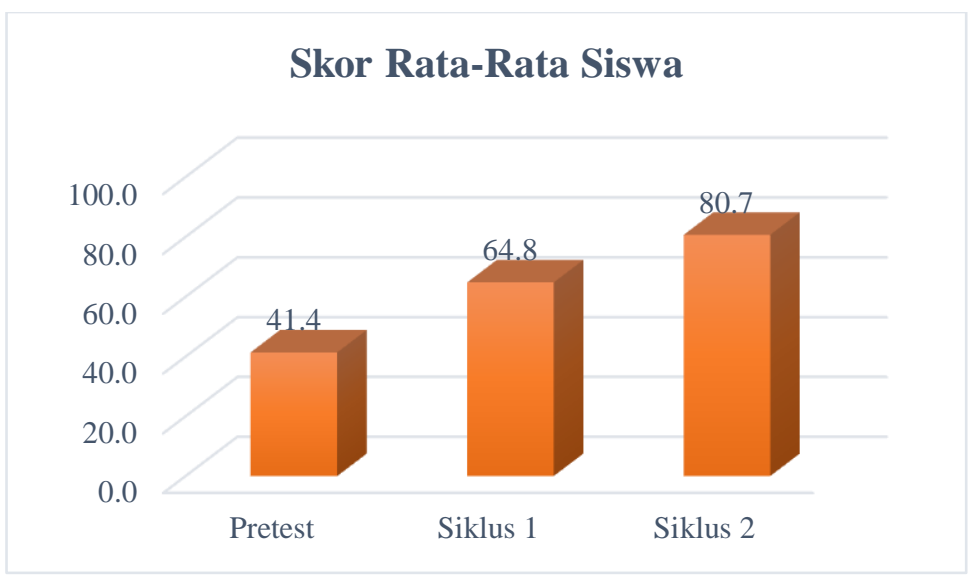

Grafik 1. Grafik Rata-Rata Nilai Siswa

Dari hasil diatas dapat disimpulkan bahwa penggunaan metode Find Someone Who dalam pembelajaran bahasa inggris dapat meningkatkan kemmapuan berbicara siswa secara signifikan. Hal tersebut ditunjukkan dengan adanya peningkatan skor rata-rata siswa yang awalnya hanya berada pada poin 41.4 menjadi 80.7 di siklus kedua.

Ada beberapa faktor yang mendukung keberhasilan penelitian ini. Pertama, metode Find Someone Who mengharuskan siswa untuk berbicara dengan bertanya dan mencari jawaban dari pertanyaan yang ada dalam lembar kerja yang dibagikan. Siswa harus secara individu dan aktif untuk melengkapi jawaban dalam lembar kerjanya. Sehingga, secara tidak langsung keharusan mereka untuk berbicara melatih mereka meningkatkan kemampuan berbicaranya dalam setiap pertemuan. Selain itu metode ini menyenangkan dan secara tidak sadar siswa sudah berbahasa inggris di dalam kelas. Hal ini senada 
dengan pendapat Sholilat (2013) yang menyatakan bahwa model pembelajaran Find Someone Who dirancang untuk membuat siswa belajar dengan cara menyenangkan.

Kedua, meningkatkan motivasi siswa untuk lebih aktif siswa dalam belajar. Kemampuan siswa dalam berbicara bahasa inggris tidak akan meningkat jika siswanya hanya diam dan menulis. Melalui metode pembelajaran Find Someone Who ini siswa dapat bergerak secara aktif didalam kelas bahkan berkeliling dalam kelas dan bertanya kepada temannya satu persatu untuk melengkapi jawaban dalam lembar kerja (Nurhaniyah, 2015). Ditambah lagi, peneliti memberikan waktu kepada mereka untuk setiap kegiatan sehingga menambah keaktifan siswa dalam berbicara. Hal tersebut merupakan salah satu kelebihan dari metode Find Someone Who (Kurnia, 2017).

Ketiga, siswa lebih berani dalam mengungkapkan pendapatnya. Dalam proses pembelajaran menggunakan metode Find Someone Who siswa diharuskan untuk menjawab pertanyaan dari temannya yang mendatanginya. Sehingga, siswa lebih berani mengungkapkan pendapatnya dalam bahasa inggris dan tingkat kepercayaan dirinya pun meningkat. Namun, jika terjadi kesalahan tata bahasa dalam proses menjawab pertanyaannya peneliti akan mengoreksinya secara langsung sehingga siswa tidak takut untuk berbicara. Marlina (2016) menyatakan hal yang sama dalam penelitiannya bahwa Metode Find Someone Who membuat siswa lebib berani mengungkapkan pendapatnya.

\section{Kesimpulan dan Saran}

Penerapan Metode Find Someone Who dalam pembelajaran bahasa inggris dalam meningkatkan kemampuan berbicara siswa. Hal ini dibuktikan dengan adanya peningkatan rata-rata skor siswa pada pretest yang hanya 41.4 dan termasuk dalam kategori sangat buruk sedangkan rata-rata skor siswa pada siklus 1 mengalami peningkatan yaitu 64.8 yang termasuk dalam kategori cukup. Pada akhirnya, di siklus 2 skor rata-rata siswa yaitu 80.7 yang sudah masuk dalam ketegori baik dan mencapai KKM. Hasil tersebut dapat dijadikan acuan untuk para guru bahasa inggris di SMP Muhammadiyah Aimas, khususnya kelas VIIB untuk menggunakan metode pembelajaran ini.

\section{Referensi}

Depdiknas. (2006). Rancangan Penilian Hasil Belajar. Jakarta: Depdiknas

Jumrawarsi. (2017). Pengaruh Model Pembelajaran Kooperatif Learning Tipe Find Someone Who Terhadap Hasil Belajar Matematika Siswa. Jurnal Gantang, 2(2), 123-131.

Kurnia, N., Degeng, S.N.I., \& Soetjipto, E.B. (2017). The Implementation of Find Someone Who and Two Stay Two Stray Models to Improve Students' Self-Efficacy And Social Studies Learning Outcomes. Journal of Research \& Method in Education, 7 (2), 66-70.

Marlina, L., Soetjipto, B.E., Hadi, S. 2016. The Implementation of Rally Coach and Find Someone Who Model To Enhance Social Skills and SocialStudies Learning Outcomes. Journal of Research \& Method in Education (IOSR-JRME), 6 (3): 86-92.

Nurhaniyah, B., Soetjipto, B.E \& Hanurawan, F. 2015. The Implementation of Collaborative Learning Model Find Someone who and Flash Card game to enhance Social Studies Learning Motivation for the Fifth Grade Students. Journal of Education and Practice, 6(17): 166-171.

Permendikbud Republik Indonesia Nomor 54 (2013). Tentang Standar Kompetensi Lulusan $(S K L)$.

Sholihat, S. (2014). Efektivitas Model Pembelajaran Kooperatif Teknik Find Someone Who Dalam Meningkatkan Penguasaan Kosakata Bahasa Jepang Tingkat Dasar (Online),(http://jepang.upi.edu/jurnal/).

Kagan, S. (2009). Kagan Cooperative Learning. San Clemente: Kagan Publishing. 
Suherman, E. (2003). Strategi Pembelajaran Matematika Kontemporer. Bandung: PT Remaja Rosdakarya.

Tahir, M. (2015). Pengantar Metodologi Penelitian Pendidikani. Makasar: Universitas Muhammadiyah Makasar.

Thornbury, S. (2005). How to Teach Speaking. Essex: Longman

Tsui, A. B. M., \& Tollefson, J. W. (2007). Language policy and the construction of national cultural identity. In A. B. M. Tsui \& J. W. Tollefson (Eds.), Language policy, culture, and identity in Asian contexts (pp. 1-21). London: Lawrence Erlbaum. 